\title{
The Effect of Partnership Presence and Support on HIV Viral Suppression Among Serodiscordant Partnered and Single Heterosexual HIV-Positive Individuals in Brazil
}

\author{
Zoë Baker ${ }^{1}$ (1) Pamina Gorbach ${ }^{2} \cdot$ Marineide Gonçalves de Melo ${ }^{3} \cdot$ Ivana Varela $^{3} \cdot$ Eduardo Sprinz $^{3} \cdot$ Breno Santos $^{3}$. \\ Tauí de Melo Rocha ${ }^{3} \cdot$ Mariana Simon $^{3} \cdot$ Marcelo Almeida $^{3} \cdot$ Rita Lira $^{3} \cdot$ Maria Cristina Chaves $^{3} \cdot$ Tara Kerin $^{4}$. \\ Karin Nielsen-Saines ${ }^{4}$
}

Accepted: 7 December 2020 / Published online: 2 January 2021

(c) The Author(s), under exclusive licence to Springer Science+Business Media, LLC part of Springer Nature 2021

\begin{abstract}
HIV-negative individuals in serodiscordant partnerships experience reduced risk of HIV acquisition when their partners adhere to ART and achieve undetectable viral loads. Partnership support may encourage ART adherence, reducing viral load and the risk of HIV transmission. This study aims to determine whether HIV viral suppression is associated with partnership status and partnership support among $201 \mathrm{HIV}$ positive (HIV+ individuals in serodiscordant partnerships and 100 HIV+ unpartnered individuals receiving care at Hospital Nossa Senhora da Conceição in Porto Alegre, Brazil between 2014 and 2016. Clinical data and patient-reported questionnaire data were assessed, and propensity scores were used to control for confounding variables in adjusted logistic regression models. Viral suppression did not significantly differ between HIV+ partnered (78.5\% virally suppressed) and unpartnered (76.0\% virally suppressed) individuals. Among individuals in partnerships, viral suppression was significantly associated with having a partner who attended monthly clinic visits (AOR 2.99; 95\% CI 1.00-8.93). Instrumental social support-attending monthly visits-may improve the odds of viral suppression among HIV+individuals in serodiscordant relationships.
\end{abstract}

Keywords HIV · Partnership · Viral load · ART · Adherence

\section{Introduction}

As sex is the primary route of transmission for HIV acquisition worldwide, HIV-negative (HIV-) individuals in sexual partnerships with HIV-positive (HIV+) individuals are particularly vulnerable to contracting the disease. The risk of HIV acquisition among HIV - individuals in serodiscordant partnerships is not uniform, however, and may be dependent on the presence of other sexually transmitted infections (STIs), condom use, sexual behaviors, and male circumcision, in addition to the HIV + partner's antiretroviral therapy (ART) adherence, viral load, and disease stage [1-6]. ART adherence is considered one of the most important factors in reducing the risk of seroconversion for HIV- individuals in serodiscordant partnerships [1,7-10]. Consistent ART use is linked to viral load suppression, decreased genital secretion of HIV, and significantly lower risk of HIV transmission during sex $[1,7-10]$. Despite its vast benefits, adherence to ART, as with medication adherence for other chronic conditions, remains a challenge [11]. 
An international clinical trial among serodiscordant partners-HIV Prevention Trials Network (HPTN) 052enrolled 1,763 participants across 13 study sites located in Brazil, the United States, India, Thailand, Kenya, Zimbabwe, Malawi, Botswana, and South Africa from 2007-2010 [7, 12, 13]. Results from HPTN-052 indicated that ART treatment of the HIV+ partner could decrease seroconversion risk by $96 \%[7,12]$. Several prior studies have indicated that a large proportion of partners in HIV serodiscordant partnerships report engaging in unprotected sex, underscoring the importance of sufficient ART adherence in this population [13-15]. In instances in which pre-exposure prophylaxis (PrEP) is not typically offered to HIV - individuals in serodiscordant partnerships, ART adherence is particularly crucial. At the time the current study took place, PrEP was not publicly available in Brazil, and became freely available in the country in May 2017 [16].

The incidence of HIV in Brazil was an estimated 48,000 new cases per year in 2019, accounting for $49 \%$ of all new infections in Latin America [17]. The prevalence of HIV in the country is considered stable, with 920,000 individuals living with HIV [17]. Of all HIV+individuals in Brazil, it is estimated that approximately $69 \%$ receive ART and $65 \%$ become virally suppressed [17]. Although women in Brazil are typically tested for HIV during pregnancy, missed opportunities to identify and treat HIV+ pregnant women have been identified in up to one third of cases [18]. Additionally, partner testing is not typically offered, allowing serodiscordant partnerships to remain unidentified and potentially leading to new cases of HIV infection [19]. Rio Grande do Sul, Brazil's southernmost state, and its largest and capital city, Porto Alegre, are important areas for HIV prevention efforts in Brazil. In previous years, Rio Grande do Sul and Porto Alegre have faced consistently higher HIV incidence rates and mortality rates from AIDS than the national average [17, 20]. HIV prevention efforts, particularly among serodiscordant partners, are crucial to reducing the high burden of HIV in Porto Alegre. Hospital Nossa Senhora da Conceição, the largest public tertiary care institution in Rio Grande do Sul, provides HIV/AIDS care in Porto Alegre, and is a critical site for HIV prevention, treatment, and research.

Social support can influence medication adherence, and may be defined as an individual's perception and experience of being cared for, receipt of assistance from others, and involvement in a supportive social network [21-23]. Facets of social support include emotional support-the provision of care, empathy, love, and trust-, instrumental supportthe provision of goods and services-, and informational support-the provision of information during times of stress [23]. Social support has been found to be positively associated with medication adherence among individuals suffering from a variety of chronic conditions, including HIV/ AIDS [24-27]. For those suffering with long-term illnesses, romantic partners may be the main source of social support [28]. HIV+ individuals with HIV-partners may also be increasingly likely to adhere to ART in order to prevent HIV transmission to their partner. Such "altruistic adherence" has been documented among serodiscordant partners in HPTN-052 [29]. The effects of partnership on ART adherence, however, remains ambiguous [30, 31].

The aim of this study was to determine the rates of viral suppression among HIV+ partnered and unpartnered individuals, and to determine whether various aspects of social support were associated with viral suppression among HIV+ partnered individuals.

\section{Methods}

Four hundred and two heterosexual individuals in serodiscordant partnerships (201 HIV+; $201 \mathrm{HIV}-$ ) and 100 $\mathrm{HIV}+$ unpartnered individuals were recruited between 2014 and 2016 for inclusion in a cross-sectional study named TRIPAI. Participants were recruited from an HIV outpatient clinic at Hospital Conceição and from an HIV serodiscordant outpatient clinic at Hospital Conceicao, a clinic created at the time of site participation in HPTN-052. In order to be eligible for enrollment in TRIPAI, HIV+ serodiscordant partners had to be a member of a serodiscordant partnership for at least three months, have disclosed their HIV status to their partner, and have their partner also consent and be eligible to participate in the study. HIV+ unpartnered individuals had to be unpartnered at baseline for inclusion in the study. All participants had to be at least 18 years old, and all HIV+ individuals had to be on ART for at least three months for inclusion in TRIPAI. All study participants were heterosexual.

Audio Computer-Assisted Self-Interview (ACASI) questionnaires were completed by participants at the time of the study visit to collect data on demographics, sexual behaviors, partnership dynamics and support, and self-reported ART adherence. Partnership presence, partner's provision of emotional, instrumental, and information support, and satisfaction with partner's provision of social support were assessed in baseline screenings and ACASI questions (Table 1). For HIV+ individuals, HIV viral load and CD4 cell count were also measured, and screenings for STIs were performed. Individuals were considered virally suppressed if their plasma viral load was undetectable ( $<40$ copies/ ml) after three months of initiating ART. All HIV- subjects underwent rapid HIV tests.

The number and proportion of HIV+ partnered individuals reporting various aspects of partnership support were reported in the sample overall, and by gender. Pearson chisquare tests were used to assess whether receipt of various facets of partnership support significantly varied by gender. 
The proportion of HIV+ individuals achieving viral suppression were reported overall, and by partnership status. Logistic regression models were utilized to examine the associations between partnership presence and undetectable plasma viral load ( $<40$ copies/ml vs. $\geq 40$ copies $/ \mathrm{ml}$ ), and the associations between facets of partnership support and undetectable viral load. Confounding variables were identified using Directed Acyclic Graphs (DAGs; Online Appendices 1 and 2), and included in adjusted logistic regression based on models based on DAG identification of the minimum number of confounding variables necessary to appropriately control for confounding [32, 33]. Propensity scores were used as covariates in adjusted logistic regression models to control for confounding variables. Using propensity scores as covariates in regression has been identified as a valid method for confounder control in observational studies with small sample sizes $[34,35]$. All analyses were completed using SAS v9.4.

The study protocol was reviewed and approved by the Institutional Review Boards (IRBs) in Brazil and at UCLA.

\section{Results}

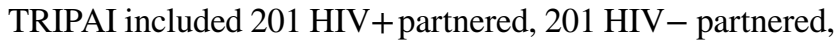
and $100 \mathrm{HIV}+$ unpartnered adult participants. HIV+ individuals were on ART for a median of 4.2 years before study enrollment, with no significant difference in median time on ART between partnered and unpartnered individuals (4.5 versus 4.0 years; $p=0.31$ ) [36]. Approximately $70 \%$ of HIV+individuals were female; consequently, HIV- partners were more frequently male (Table 2). Most participants (63.0\%) identified as white, $22.4 \%$ as black, and $15.6 \%$ as mixed race. The majority (64.1\%) resided in Porto Alegre, with the remainder living in surrounding cities in Rio Grande do Sul. Education levels of TRIPAI participants were generally low, with $66.1 \%$ completing elementary school or less. Eighty percent of TRIPAI participants had children, and $17.9 \%$ of women were pregnant or had attempted to conceive in the past year. Approximately $96 \%$ of individuals in partnerships were sexually active in the past month, compared to $60.2 \%$ of unpartnered individuals. Condom use in the past month appeared to be less common among partnered than unpartnered individuals; among individuals who were sexually active in the past month, only $46.0 \%$ of partnered individuals reported always using condoms in the past month, compared to $81.8 \%$ of unpartnered individuals.

Overall, $35.9 \%$ of HIV+individuals in serodiscordant partnerships reported that their partner attended monthly visits with them, and $43.5 \%$ stated that their partner offered emotional support in taking ART over the past year (Table 3). Approximately three quarters of individuals reported that their partner had reminded them to take ART in the past year, and $45.8 \%$ of partners "actively reminded" their HIV+ partners to take ART (Table 3). Over $80 \%$ of HIV+ partners stated that they were "very satisfied" with the support their partner provided (Table 2). Several measures of partnership support among HIV+ partnered TRIPAI participants indicated disparities by gender. Almost three quarters of HIV+ women $(\mathrm{n}=101 ; 72.7 \%)$ received financial $/$ material support from their partners, compared to only $42.6 \%$ $(n=26)$ of men $\left(X^{2} p<0.001\right.$; Table 3$)$. Additionally, $78.3 \%$

Table 1 Partnership variables of interest reported in baseline screenings and ACASI questionnaires, including partnership presence, partners' provision of social support, and satisfaction with partnership support

\begin{tabular}{|c|c|c|c|}
\hline Questionnaire type & Domain & Question & Possible responses \\
\hline Baseline screening & Partnership presence & $\begin{array}{l}\text { Are you currently in a romantic partnership lasting at least } 3 \text { months with an } \\
\text { individual of the opposite sex? }\end{array}$ & $\begin{array}{l}\text { Yes } \\
\text { No }\end{array}$ \\
\hline \multirow[t]{6}{*}{ ACASI } & Emotional support & $\begin{array}{l}\text { In the past year, my partner has offered emotional support in taking antiretro- } \\
\text { virals (ARVs) }\end{array}$ & $\begin{array}{l}\text { Yes } \\
\text { No }\end{array}$ \\
\hline & \multirow[t]{2}{*}{ Instrumental support } & Does your partner provide you with financial and/or material support? & $\begin{array}{l}\text { Yes } \\
\text { No }\end{array}$ \\
\hline & & In the past year, my partner has attended monthly visits with me & $\begin{array}{l}\text { Yes } \\
\text { No }\end{array}$ \\
\hline & \multirow[t]{2}{*}{ Informational support } & In the past year, my partner has reminded me to take ARVs & $\begin{array}{l}\text { Yes } \\
\text { No }\end{array}$ \\
\hline & & $\begin{array}{l}\text { In the past year, how active was your partner in reminding you to take your } \\
\text { ARVs? }\end{array}$ & $\begin{array}{l}\text { Very active } \\
\text { Active } \\
\text { Reasonably active } \\
\text { Not active }\end{array}$ \\
\hline & $\begin{array}{l}\text { Overall satisfaction } \\
\text { with partner sup- } \\
\text { port }\end{array}$ & $\begin{array}{l}\text { In general, how satisfied are you with the overall support you get from your } \\
\text { partner? }\end{array}$ & $\begin{array}{l}\text { Very satisfied } \\
\text { A little satisfied } \\
\text { A little dissatisfied } \\
\text { Very dissatisfied }\end{array}$ \\
\hline
\end{tabular}


Table 2 Sociodemographics and viral suppression of HIV+ participants in partnerships, their serodiscordant (HIV-) partners, and the HIV+ unpartnered individuals in TRIPAI $(n=502)$

\begin{tabular}{|c|c|c|c|c|}
\hline & \multicolumn{2}{|c|}{ Partnered $(n=402)$} & \multirow{2}{*}{$\begin{array}{l}\text { Unpartnered } \\
(\mathrm{n}=100) \\
\mathrm{HIV+} \\
\mathrm{n}(\%)^{\mathrm{a}}\end{array}$} & \multirow{2}{*}{$\begin{array}{l}\text { Total }(\mathrm{n}=502) \\
\mathrm{n}(\%)^{\mathrm{a}}\end{array}$} \\
\hline & $\begin{array}{l}\mathrm{HIV}+(\mathrm{n}=201) \\
\mathrm{n}(\%)^{\mathrm{a}}\end{array}$ & $\begin{array}{l}\text { HIV- }(\mathrm{n}=201) \\
\mathrm{n}(\%)^{\mathrm{a}}\end{array}$ & & \\
\hline \multicolumn{5}{|l|}{ Age } \\
\hline $18-29$ & $39(19.4)$ & $37(18.5)$ & $11(11.0)$ & $87(17.4)$ \\
\hline $30-39$ & $79(39.3)$ & $72(36.0)$ & $25(36.0)$ & $176(35.1)$ \\
\hline $40-49$ & $60(29.9)$ & $51(25.5)$ & $30(30.0)$ & $141(28.1)$ \\
\hline $50+$ & $23(11.4)$ & $40(20.0)$ & $34(34.0)$ & $97(19.4)$ \\
\hline \multicolumn{5}{|l|}{ Gender } \\
\hline Female & $139(69.2)$ & $62(30.8)$ & $68(68.0)$ & $269(58.6)$ \\
\hline Male & $62(30.9)$ & $139(69.2)$ & $32(32.0)$ & $233(46.4)$ \\
\hline \multicolumn{5}{|l|}{ Race } \\
\hline Black & $53(26.4)$ & $39(19.6)$ & $19(19.0)$ & $111(22.4)$ \\
\hline Mixed & $29(14.4)$ & $31(15.6)$ & $17(17.0)$ & $77(15.6)$ \\
\hline White & $119(59.2)$ & $129(64.5)$ & $64(64.0)$ & $312(63.0)$ \\
\hline \multicolumn{5}{|l|}{ City of residence } \\
\hline Porto Alegre & $109(62.6)$ & $109(62.6)$ & $53(65.4)$ & $271(64.1)$ \\
\hline Other & $65(37.4)$ & $65(37.4)$ & $28(34.6)$ & $152(35.9)$ \\
\hline \multicolumn{5}{|l|}{ Education level } \\
\hline Less than elementary school & $85(42.5)$ & $74(37.2)$ & $43(43.0)$ & $202(40.5)$ \\
\hline Completed elementary school to some high school & $47(23.5)$ & $51(25.6)$ & $32(32.0)$ & $130(26.1)$ \\
\hline Completed high school or higher & $68(34.0)$ & $74(37.2)$ & $25(25.0)$ & $167(33.5)$ \\
\hline \multicolumn{5}{|l|}{ Have children } \\
\hline No & $31(15.4)$ & $39(19.7)$ & $26(26.0)$ & $96(19.2)$ \\
\hline Yes & $170(84.6)$ & $159(80.3)$ & $74(74.0)$ & $403(80.8)$ \\
\hline \multicolumn{5}{|l|}{ Pregnancy/attempted pregnancy in past year ${ }^{\mathrm{b}}$} \\
\hline No & $99(71.2)$ & $57(93.4)$ & $64(94.1)$ & $220(82.1)$ \\
\hline Yes & $40(28.8)$ & $4(6.6)$ & $4(5.9)$ & $48(17.9)$ \\
\hline \multicolumn{5}{|l|}{ Sexually active in past month } \\
\hline No & $8(4.1)$ & $8(4.2)$ & $56(60.2)$ & $72(15.0)$ \\
\hline Yes & $186(95.9)$ & $184(95.8)$ & $37(39.8)$ & $407(85.0)$ \\
\hline \multicolumn{5}{|l|}{ Condom use in past month ${ }^{\mathrm{c}}$} \\
\hline Never & $67(36.0)$ & $68(36.6)$ & $5(15.2)$ & $140(34.6)$ \\
\hline Sometimes & 37 (19.9) & $29(15.6)$ & $1(3.0)$ & $67(16.5)$ \\
\hline Always & $82(44.1)$ & $89(47.8)$ & $27(81.8)$ & $198(48.9)$ \\
\hline \multicolumn{5}{|l|}{ Viral load } \\
\hline Undetectable $(<40$ copies $/ \mathrm{ml})$ & $157(78.5)$ & - & $76(76.0)$ & $233(77.7)$ \\
\hline Detectable & 43 (21.5) & - & $24(24.0)$ & $67(22.3)$ \\
\hline
\end{tabular}

${ }^{\mathrm{a}}$ Missing values excluded from percentage calculations

${ }^{\mathrm{b}}$ Among females

${ }^{\mathrm{c}}$ Among individuals sexually active in past month

of HIV+ women had partners who reminded them to take ART in the past year, compared with $61.5 \%$ of $\mathrm{HIV}+$ men $\left(\mathrm{X}^{2}=0.05\right.$; Table 3$)$.

The majority of HIV+ individuals (77.7\%) enrolled in TRIPAI had undetectable viral loads at the time of the study (Table 1). Seventy-six percent of unpartnered HIV+individuals achieved viral suppression, compared to $78.5 \%$ of partnered HIV+ individuals. Being in a serodiscordant partnership (vs. being unpartnered) was not associated with viral suppression (adjusted odds ratio (AOR) 1.35 ; 95\% CI 0.75-2.46; $p=0.30$; Table 4).

Among the $201 \mathrm{HIV}+$ partnered individuals in TRIPAI, having a partner who attended monthly visits with the individual was significantly associated with viral suppression 
Table 3 Proportions of HIV+individuals in partnerships reporting partnership support, and difference between female and male individuals' receipt of partnership support according to Pearson $X^{2}$ tests $(n=201)$

\begin{tabular}{|c|c|c|c|c|}
\hline & $\begin{array}{l}\text { All HIV+ individu- } \\
\text { als in partnerships } \\
(\mathrm{n}=201) \\
\mathrm{n}(\%)\end{array}$ & $\begin{array}{l}\text { HIV+ part- } \\
\text { ner female } \\
(\mathrm{n}=139) \\
\mathrm{n}(\%)\end{array}$ & $\begin{array}{l}\text { HIV+ partner male } \\
(\mathrm{n}=62) \\
\mathrm{n}(\%)\end{array}$ & $\mathrm{X}^{2}$ Statistic (p-value) \\
\hline \multicolumn{5}{|c|}{ Partner provides financial/material support } \\
\hline Yes & $127(64.5)$ & $101(72.7)^{*}$ & $26(42.6)^{*}$ & $18.41(<0.001)^{*}$ \\
\hline No & $70(35.5)$ & $35(25.7)^{*}$ & $35(57.4)^{*}$ & \\
\hline \multicolumn{5}{|c|}{$\begin{array}{l}\text { In the past year, partner has reminded individual to take } \\
\quad A R T\end{array}$} \\
\hline Yes & $96(73.3)$ & $72(78.3)^{*}$ & $24(61.5)^{*}$ & $3.91(0.05)^{*}$ \\
\hline No & $35(26.7)$ & $20(21.7)^{*}$ & $15(38.5)^{*}$ & \\
\hline \multicolumn{5}{|c|}{$\begin{array}{l}\text { In the past year, how active was partner in reminding } \\
\text { individual to take ART? }\end{array}$} \\
\hline Very active & $73(37.4)$ & $46(33.8)$ & $27(45.8)$ & $3.74(0.29)$ \\
\hline Active & $35(17.9)$ & $28(20.6)$ & $7(11.9)$ & \\
\hline Reasonably active & $32(16.4)$ & $24(17.6)$ & $8(13.6)$ & \\
\hline Not active & $55(28.2)$ & $38(27.9)$ & $17(28.8)$ & \\
\hline \multicolumn{5}{|c|}{ In the past year, partner attended monthly visits } \\
\hline Yes & $47(35.9)$ & $34(37.0)$ & $13(33.3)$ & $0.16(0.69)$ \\
\hline No & $84(64.1)$ & $58(63.0)$ & $26(66.7)$ & \\
\hline \multicolumn{5}{|c|}{$\begin{array}{l}\text { In the past year, partner offered emotional support in } \\
\text { taking ART }\end{array}$} \\
\hline Yes & $57(43.5)$ & $38(41.3)$ & $19(48.7)$ & $0.61(0.43)$ \\
\hline No & $74(56.5)$ & $54(58.7)$ & $20(51.3)$ & \\
\hline \multicolumn{5}{|c|}{ Overall satisfaction with partner support } \\
\hline Very satisfied & $159(82.4)$ & $108(80.0)$ & $51(87.9)$ & $5.69(0.13)$ \\
\hline A little satisfied & $22(11.4)$ & $20(14.8)$ & $2(3.4)$ & \\
\hline A little unsatisfied & $7(3.6)$ & $4(3.0)$ & $3(5.2)$ & \\
\hline Very unsatisfied & $5(2.6)$ & $3(2.2)$ & $2(3.4)$ & \\
\hline
\end{tabular}

*Statistically significant differences in partnership support by gender according to Pearson $\mathrm{X}^{2}$ tests; $\mathrm{p}$-value $<0.05$

Table 4 Crude and adjusted logistic regression models, examining the association between exploratory variables and outcomes of interest,

\begin{tabular}{|c|c|c|c|c|c|c|c|}
\hline \multirow[t]{2}{*}{ Group of anaysis } & \multirow[t]{2}{*}{ Exploratory variable } & \multicolumn{3}{|c|}{ Crude Model } & \multicolumn{3}{|c|}{ Adjusted model $^{\mathrm{a}}$} \\
\hline & & OR & $95 \% \mathrm{CI}$ & p-value & AOR & $95 \% \mathrm{CI}$ & p-value \\
\hline All HIV+Individuals & Partnership presence & 1.15 & $0.65,2.04$ & 0.62 & 1.37 & $0.76,2.48$ & 0.30 \\
\hline \multirow[t]{6}{*}{ HIV+ Partnered Individuals } & Partner attends monthly visits & 2.55 & $0.89,7.30$ & 0.08 & 2.99 & $1.00,8.93$ & $0.05 *$ \\
\hline & Partner reminds to take ART & 0.71 & $0.24,2.09$ & 0.54 & 0.63 & $0.20,1.96$ & 0.42 \\
\hline & Partner actively reminds to take ART & 1.70 & $0.80,3.59$ & 0.17 & 2.12 & $0.94,4.77$ & 0.07 \\
\hline & Partner provides financial support & 0.72 & $0.34,1.53$ & 0.40 & 0.68 & $0.31,1.52$ & 0.35 \\
\hline & Partner provides emotional support & 0.57 & $0.23,1.42$ & 0.23 & 1.72 & $0.67,4.34$ & 0.26 \\
\hline & Satisfaction with partner support & 0.84 & $0.32,2.21$ & 0.73 & 0.96 & $0.36,2.56$ & 0.93 \\
\hline
\end{tabular}

${ }^{*}$ p-value $<0.05$

${ }^{a}$ All models adjusted for age, gender, and education level; analyses assessing partnership support and satisfaction also adjusted for whether participant had children

(Table 4). Individuals with partners who attended monthly visits had 2.99 times greater odds of viral suppression, compared to individuals with partners who did not attend visits
(95\% CI 1.00-8.93; $\mathrm{p}=0.05$; Table 4). Other partnership support measures of interest, including provision of emotional support in taking ART, provision of financial/material 
support, reminding partners to take ART, and level satisfaction with partner support, were not significantly associated with viral suppression.

\section{Discussion}

Among HIV+ participants in TRIPAI, rates of viral suppression were somewhat higher than rates of viral suppression in Brazil overall, which are estimated at 65\% [17]. Participants in TRIPAI may be more likely to be virally suppressed than other HIV+ individuals in Brazil because TRIPAI participant have thus far been retained in HIV/AIDS care at Hospital Nossa Senhora da Conceição, and may have access to increased resources to improve adherence due to their involvement in the study. Research among HIV+ individuals, including in Brazil, has indicated that retention in care is associated with improved ART adherence, viral suppression, and decreased risk of mortality [37].

Overall, partnership status was not associated with viral suppression. It appears that there may be barriers to viral suppression among some individuals that affect both partnered and unpartnered individuals, and that partnership presence alone may not be enough to overcome other barriers to sustaining care. Individuals who are unpartnered may compensate for their lack of a partner by securing support that may encourage ART adherence from other members of their social network, including family and friends. Previous research among HIV+individuals has found that the number of close friends and family members is significantly associated with greater perceived social support, which may encourage medication adherence $[38,39]$. Additionally, partnership presence does not guarantee strong social support that improves ART-taking; partnerships in distress and/or partners with their own health issues may not provide support. Even when an individual has strong social support, other factors, such as physical and mental health issues, competing priorities, personal beliefs, risk behaviors, and limited access to health services may prevent an individual from adhering to ART and achieving viral suppression [38].

Attending monthly visits was significantly associated with viral suppression among both men and women. This is consistent with prior research, which has indicated that practical support, such as accompanying a partner to the clinic, has a greater impact on medication adherence than emotional support [40, 41]. Attending an HIV+ partner's clinic visits has also been associated with other positive health outcomes; a study among HIV+ pregnant women in Kenya found that the risk of vertical transmission was significantly lower among women whose partners attended clinic visits [41]. Partner attendance in prenatal care visits is also associated with a higher level of satisfaction with partner by pregnant women and a higher rate of acceptance of HIV testing by men in Porto Alegre [42]. Greater involvement of partners in HIV care may ultimately lead to viral suppression; research among HIV-serodiscordant partners in New York found that partner-focused interventions aiming to identify barriers to ART adherence and optimize partner communication resulted in significantly improved ART adherence and reduced viral load [27].

In the past, Brazil has taken proactive measures in responding to the HIV crisis, offering free ART in 1996, and treating all people living with HIV with ART regardless of CD4 counts in 2013 [43]. Ensuring that individuals living with HIV in Brazil can continue to receive adequate care for HIV in the years ahead is critical. There are concerns that health resources for people living with HIV in Brazil be drastically reduced in the coming years, as President Jair Bolsonaro's administration supports downsizing the Sistema Único de Saúde (SUS), the country's public health system [44]. The administration's ineffective response to the COVID-19 pandemic underscores concerns that national health crises, including HIV/AIDS, may be inadequately managed into the future [45].

\section{Limitations}

One limitation of this study is the cross-sectional nature of TRIPAI, which prevents the assessment of changes in variables over time. Additionally, TRIPAI may be vulnerable to biases associated with observational data, such as selection bias due to subject self-selection. HIV- partners who enrolled in TRIPAI were required to attend a clinic visit and complete a questionnaire asking about the support they provided to their partner; individuals who agreed to participate in TRIPAI may be more supportive partners than HIV- individuals in serodiscordant partnerships who declined to participate. Additionally, since inclusion criteria included partner disclosure of HIV status, individuals who felt they could not disclose their HIV status to their partners were excluded. Prior research has indicated that among HIV-serodiscordant partners, HIV status disclosure was significantly associated with ART adherence [40]. It is thus possible that the participants enrolled in TRIPAI are not representative of all HIV-serodiscordant partners in Brazil, and that individuals who feel unable to disclose their HIV status to their partners may face reduced rates of ART adherence and viral suppression.

It is also possible that there are instances of unmeasured confounding in this study. HIV viral suppression may be influenced by treatment regimen, baseline viral load and CD4 count, and any previous ART use and/or ART ressistance [43]. These factors were not controlled for in this analysis, and could confound the results of the study. Additionally, factors such as depression and stress likely influence 
level of partner support, ART adherence, and viral suppression, but were not measured in this study. In previous studies among serodiscordant partners, mental health, and specifically depression, was associated with ART non-adherence [29]. Additionally, some of the data collected in TRIPAI may be considered sensitive, and may thus be prone to misclassification. While sensitive information collected via ACASI tends to produce less social desirability bias than face-to-face interviews, it is possible that individuals still underreport socially undesirable behaviors (e.g. substance use) and overreport socially desirable behaviors (e.g. condom use) in ACASI.

\section{Conclusion}

Overall, the proportion of HIV+ individuals achieving viral suppression was relatively high in this population. Having an HIV - partner vs. being unpartnered did not appear to be associated with improved odds of viral suppression. While most measures of partnership support were not significantly associated with viral suppression, attending clinic visits with partners was identified as being positively associated with viral suppression among serodiscordant partnered individuals. Barriers to achieving viral suppression are likely present among both HIV+ partnered and unpartnered individuals in Brazil.

Funding Funding for this study was provided by the UCLA AIDS Institute and the National Institute of Allergy and Infectious Diseases (Award Number: AI28697).

\section{Compliance with Ethical Standards}

Conflict of interest The authors have no conflicts of interest to declare.

Ethical Approval This research involves human participants and was reviewed and approved by the Institutional Review Board at UCLA and at the study site in Brazil.

Informed Consent Informed consent was obtained from all participants before study activities took place.

\section{References}

1. Melo MG, Santos BR, De Cassia LR, Varella IS, Turella ML, Rocha TM, et al. Sexual transmission of HIV-1 among serodiscordant couples in Porto Alegre, southern Brazil. Sex Transm Dis. 2008;35(11):912-5.

2. Shuper PA, Neuman M, Kanteres F, Baliunas D, Joharchi N, Rehm J. Causal considerations on alcohol and HIV/AIDS-a systematic review. Alcohol Alcohol. 2010;45(2):159-66.

3. Fritz K, Morojele N, Kalichman S. Alcohol: the forgotten drug in HIV/AIDS. Lancet. 2010;376(9739):398-400.
4. Kalichman SC, Pellowski J, Turner C. Prevalence of sexually transmitted co-infections in people living with HIV/AIDS: systematic review with implications for using HIV treatments for prevention. Sex Transm Infect. 2011;87(3):183-90.

5. Serwadda D, Wawer MJ, Makumbi F, Kong X, Kigozi G, Gravitt $\mathrm{P}$, et al. Circumcision of HIV-infected men: effects on high-risk human papillomavirus infections in a randomized trial in Rakai, Uganda. J Infect Dis. 2010;201(10):1463-9.

6. Wawer MJ, Gray RH, Sewankambo NK, Serwadda D, Li X, Laeyendecker O, et al. Rates of HIV-1 transmission per coital act, by stage of HIV-1 infection, in Rakai, Uganda. J Infect Dis. 2005;191(9):1403-9.

7. Cohen MS, Chen YQ, McCauley M, Gamble T, Hosseinipour MC, Kumarasamy N, et al. Prevention of HIV-1 infection with early antiretroviral therapy. N Engl J Med. 2011;365(6):493-505.

8. Del Romero J, Castilla J, Hernando V, Rodriguez C, Garcia S. Combined antiretroviral treatment and heterosexual transmission of HIV-1: cross sectional and prospective cohort study. BMJ. 2010;340:c2205.

9. Reynolds SJ, Makumbi F, Nakigozi G, Kagaayi J, Gray RH, Wawer M, et al. HIV-1 transmission among HIV-1 discordant couples before and after the introduction of antiretroviral therapy. AIDS. 2011;25(4):473-7.

10. Loutfy MR, Wu W, Letchumanan M, Bondy L, Antoniou T, Margolese $\mathrm{S}$, et al. Systematic review of HIV transmission between heterosexual serodiscordant couples where the HIV-positive partner is fully suppressed on antiretroviral therapy. PLoS ONE. 2013;8(2):e55747.

11. Ortego C, Huedo-Medina TB, Llorca J, Sevilla L, Santos P, Rodriguez $\mathrm{E}$, et al. Adherence to highly active antiretroviral therapy (HAART): a meta-analysis. AIDS Behav. 2011;15(7):1381-96.

12. Cohen MS, Holmes C, Padian N, Wolf M, Hirnschall G, Lo YR, et al. HIV treatment as prevention: how scientific discovery occurred and translated rapidly into policy for the global response. Health Aff (Millwood). 2012;31(7):1439-49.

13. Wall KM, Kilembe W, Vwalika B, Haddad LB, Lakhi S, Onwubiko U, et al. Sustained effect of couples' HIV counselling and testing on risk reduction among Zambian HIV serodiscordant couples. Sex Transm Infect. 2017;93(4):259-66.

14. van der Straten A, Gomez CA, Saul J, Quan J, Padian N. Sexual risk behaviors among heterosexual HIV serodiscordant couples in the era of post-exposure prevention and viral suppressive therapy. AIDS. 2000;14(4):F47-54.

15. Kahle EM, Hughes JP, Lingappa JR, John-Stewart G, Celum C, Nakku-Joloba E, et al. An empiric risk scoring tool for identifying high-risk heterosexual HIV-1-serodiscordant couples for targeted HIV-1 prevention. J Acquir Immune DeficSyndr. 2013;62(3):339-47.

16. Luz PM, Benzaken A, Alencar TM, Pimenta C, Veloso VG, Grinsztejn B. PrEP adopted by the brazilian national health system: what is the size of the demand? Medicine (Baltimore). 2018;97(1S Suppl 1):S75-7.

17. UNAIDS. HIV and AIDS in Brazil: AVERT; 2020. https://www. avert.org/professionals/hiv-around-world/latin-america/brazil.

18. Domingues R, Saraceni V, Leal MDC. Mother to child transmission of HIV in Brazil: data from the "Birth in Brazil study", a national hospital-based study. PLoS ONE. 2018;13(2):e0192985.

19. Melo M, Varella I, Castro A, Nielsen-Saines K, Lira R, Simon $\mathrm{M}$, et al. HIV voluntary counseling and testing of couples during maternal labor and delivery: the TRIPAI Couples study. Sex Transm Dis. 2013;40(9):704-9.

20. Pereira GFM, Shimizu HE, Bermudez XP, Hamann EM. Epidemiology of HIV and AIDS in the state of Rio Grande do Sul, Brazil, 1980-2015. EpidemiolServSaude. 2018;27(4):e2017374.

21. Klitzman S, House JS, Israel BA, Mero RP. Work stress, nonwork stress, and health. J Behav Med. 1990;13(3):221-43. 
22. Munoz-Laboy M, Ripkin A, Garcia J, Severson N. Family and work influences on stress, anxiety and depression among bisexual Latino men in the New York City metropolitan area. J Immigr Minor Health. 2015;17(6):1615-26.

23. House JS. Work stress and social support. stress A-Wsoo, editor. Reading: Addison-Wesley Pub. Co; 1981.

24. DiMatteo MR. Social support and patient adherence to medical treatment: a meta-analysis. Health Psychol. 2004;23(2):207-18.

25. Power R, Koopman C, Volk J, Israelski DM, Stone L, Chesney MA, et al. Social support, substance use, and denial in relationship to antiretroviral treatment adherence among HIV-infected persons. AIDS Patient Care STDS. 2003;17(5):245-52.

26. Spire B, Duran S, Souville M, Leport C, Raffi F, Moatti JP, et al. Adherence to highly active antiretroviral therapies (HAART) in HIV-infected patients: from a predictive to a dynamic approach. SocSci Med. 2002;54(10):1481-96.

27. Remien RH, Stirratt MJ, Dolezal C, Dognin JS, Wagner GJ, Carballo-Dieguez A, et al. Couple-focused support to improve HIV medication adherence: a randomized controlled trial. AIDS. 2005;19(8):807-14.

28. Knowlton AR, Yang C, Bohnert A, Wissow L, Chander G, Arnsten JA. Main partner factors associated with worse adherence to HAART among women in Baltimore, Maryland: a preliminary study. AIDS Care. 2011;23(9):1102-10.

29. Safren SA, Mayer KH, Ou SS, McCauley M, Grinsztejn B, Hosseinipour MC, et al. Adherence to early antiretroviral therapy: results from HPTN 052, a phase III, multinational randomized trial of ART to prevent HIV-1 sexual transmission in serodiscordant couples. J Acquir Immune DeficSyndr. 2015;69(2):234-40.

30. Protopopescu C, Raffi F, Roux P, Reynes J, Dellamonica P, Spire $\mathrm{B}$, et al. Factors associated with non-adherence to long-term highly active antiretroviral therapy: a 10 year follow-up analysis with correction for the bias induced by missing data. J AntimicrobChemother. 2009;64(3):599-606.

31. Johnson MO, Catz SL, Remien RH, Rotheram-Borus MJ, Morin SF, Charlebois E, et al. Theory-guided, empirically supported avenues for intervention on HIV medication nonadherence: findings from the Healthy Living Project. AIDS Patient Care STDS. 2003;17(12):645-56.

32. Hernan M, Robins JM. Causal inference: what if. Boca Raton: Chapman \& Hall/CRC; 2020

33. Textor J, van der Zander B, Gilthorpe MS, Liskiewicz M, Ellison GT. Robust causal inference using directed acyclic graphs: the R package "dagitty." Int J Epidemiol. 2016;45(6):1887-94.

34. Austin PC. A tutorial and case study in propensity score analysis: an application to estimating the effect of in-hospital smoking cessation counseling on mortality. MultivarBehav Res. 2011;46(1):119-51.
35. Austin PC. An Introduction to propensity score methods for reducing the effects of confounding in observational studies. MultivarBehav Res. 2011;46(3):399-424.

36. de Melo MG, Varella I, Gorbach PM, Sprinz E, Santos B, de Melo $\mathrm{RT}$, et al. Antiretroviral adherence and virologic suppression in partnered and unpartnered HIV-positive individuals in southern Brazil. PLoS ONE. 2019;14(2):e0212744.

37. Teixeira da Silva DS, Luz PM, Lake JE, Cardoso SW, Ribeiro S, Moreira RI, et al. Poor retention in early care increases risk of mortality in a Brazilian HIV-infected clinical cohort. AIDS Care. 2017;29(2):263-7.

38. Ncama BP, McInerney PA, Bhengu BR, Corless IB, Wantland DJ, Nicholas PK, et al. Social support and medication adherence in HIV disease in KwaZulu-Natal, South Africa. Int J Nurs Stud. 2008;45(12):1757-63.

39. Mancinelli S, Nielsen-Saines K, Germano P, Guidotti G, Buonomo E, Scarcella P, et al. Who will be lost? Identifying patients at risk of loss to follow-up in Malawi. The DREAM Program Experience. HIV Med. 2017;18(8):573-9.

40. Stirratt MJ, Remien RH, Smith A, Copeland OQ, Dolezal C, Krieger D, et al. The role of HIV serostatus disclosure in antiretroviral medication adherence. AIDS Behav. 2006;10(5):483-93.

41. Aluisio AR, Bosire R, Bourke B, Gatuguta A, Kiarie JN, Nduati $\mathrm{R}$, et al. Male partner participation in antenatal clinic services is associated with improved HIV-free survival among infants in Nairobi, Kenya: a prospective cohort study. J Acquir Immune DeficSyndr. 2016;73(2):169-76.

42. Yeganeh N, Simon M, Mindry D, Nielsen-Saines K, Chaves MC, Santos B, et al. Barriers and facilitators for men to attend prenatal care and obtain HIV voluntary counseling and testing in Brazil. PLoS ONE. 2017;12(4):e0175505.

43. Benzaken AS, Pereira GFM, Costa L, Tanuri A, Santos AF, Soares MA. Antiretroviral treatment, government policy and economy of HIV/AIDS in Brazil: is it time for HIV cure in the country? AIDS Res Ther. 2019;16(1):19.

44. Montenegro L, Velasque L, LeGrand S, Whetten K, De Mattos Russo Rafael R, Malta M. Public health, HIV care and prevention, human rights and democracy at a crossroad in Brazil. AIDS Behav. 2020;24(1):1-4.

45 Lancet T. COVID-19 in Brazil: "So what?": an editorial. The Lancet. 2020;395(10235):1461.

Publisher's Note Springer Nature remains neutral with regard to jurisdictional claims in published maps and institutional affiliations. 